


\title{
MOLECULAR IDENTIFICATION AND ANTIBIOGRAM OF Enterococcus spp. ISOLATED ON ENTEROCOCCUS SELECTIVE DIFFERENTIAL (ESD) MEDIA FROM MEAT, MEAT PRODUCTS AND SEAFOOD IN LIBYA
}

\author{
Hesham T. Naas ${ }^{1}$, Zaid Almajdoubi ${ }^{1}$, Aboubaker M. Garbaj ${ }^{1}$, Salah M. Azwai ${ }^{2}$, Fatim T. Gammoudi ${ }^{2}$, Said K. Abolghait ${ }^{3}$, Ashraf A. \\ Moawad $^{4}$, Ilaria Barbieri ${ }^{5}$, Hanan L. Eshamah ${ }^{l}$ and Ibrahim M. Eldaghayes $*^{2}$
}

\author{
Address(es): \\ ${ }^{1}$ Department of Food Hygiene and Control, Faculty of Veterinary Medicine, University of Tripoli, P.O. Box 13662, Tripoli, Libya. \\ ${ }^{2}$ Department of Microbiology and Parasitology, Faculty of Veterinary Medicine, University of Tripoli, P.O. Box 13662, Tripoli, Libya. \\ ${ }^{3}$ Department of Food Hygiene and Control, Faculty of Veterinary Medicine, Suez Canal University, 41522 Ismailia, Egypt. \\ ${ }^{4}$ Department of Food Hygiene and Control, Faculty of Veterinary Medicine, Cairo University, 12211 Giza, Egypt. \\ ${ }^{5}$ Istituto Zooprofilattico Sperimentale della Lombardia e dell'Emilia Romagna, Via Bianchi, 9 - 25124 Brescia, Italy.
}

*Corresponding author: ibrahim.eldaghayes@vetmed.edu.ly

doi: $\underline{10.15414 / j m b f s .2017 .6 .6 .1264-1268}$

\section{ARTICLE INFO}

Received 7. 10. 2016

Revised 30. 3. 2017

Accepted 14. 5. 2017

Published 1. 6. 2017

Regular article

OPEN $\partial_{\text {ACCESS }}$

\begin{abstract}
This study was conducted to investigate the presence of Enterococcus spp. in meat, meat products and seafood. A hundred and four samples were randomly collected from different geographic localities in Libya. The samples were subjected to microbiological analysis for enumeration and isolation of Enterococcus spp. by conventional cultural and molecular identification using PCR and partial sequencing of $16 \mathrm{~S}$ rDNA techniques. Out of 104 samples, $73(70.2 \%)$ isolates were found to be enterococci based on their cultural characteristics on ESD medium. However, out of 36 samples subjected to molecular identification, only six isolates were confirmed to be Enterococcus spp. using PCR and partial sequencing of $16 \mathrm{~S}$ rDNA technique. All enterococci strains tested for their antibiotic sensitivity profiles showed high percentage of multi-resistance phenotype. These results can be used for further studies on enterococci as an emerging food borne pathogen and its role in human infection in Libya and would suggest that meat, meat products and seafood might play a role in the spreading of enterococci through the food chain with antimicrobial resistance characteristics.
\end{abstract}

Keywords: $16 \mathrm{~S}$ rDNA, antibiogram, enterococci, food, Libya

\section{INTRODUCTION}

Enterococcus spp. is a genus of lactic acid bacteria of the phylum Firmicutes that possess Lancefield group D antigen as some of streptococci. Enterococci are Gram-positive cocci, often occur in pairs (diplococci) or short chains bacteria of the gastrointestinal tract of healthy human intestinal flora (Aarestrup et al., 2001). Enterococci are able to survive in extremes of temperature $\left(5\right.$ to $\left.60{ }^{\circ} \mathrm{C}\right)$, $\mathrm{pH}$ (4.6 to 9.9) and high sodium chloride (6.5\% w/v) (Murray, 1990). They are capable of growth in the presence of bile salts $(40 \% \mathrm{w} / \mathrm{v})($ Fisher and Phillips, 2009) and they commonly occur in foods, especially those of animal origin such as meat and milk (Giraffa, 2003).

Previously, all streptococci of fecal origin that produce group D antigen were considered as enterococci (Hartman et al., 2001). Molecular biology studies (including oligonucleotide cataloging of $16 \mathrm{~S}$ rRNA, DNA-DNA and DNA-rRNA hybridization), combined with physiological studies showed more detailed classification (Schleifer and Kilpper-Bälz, 1987). Members of this genus are: $E$. avium, E. casseliflavus, E. durans, E. faecalis, E. faecium, E. gallinarum, E. hirae, E. malodoratus and E. mundtii (Hartman et al., 2001).

Previous studies have shown that meat and meat products represent a continuous supply of commensal bacteria, including enterococci (Choi and Woo, 2013; Sharifi et al., 2013; Sparo et al., 2013). E. faecalis and E. faecium are common commensal organisms in the intestines of humans were shown to be the predominant isolates in raw meat (beef and pork carcasses) (Knudtson and Hartman, 1993). Meanwhile, E. faecalis was the most frequent isolate among the Gram-positive cocci found in chicken meat (Turtura and Lorenzelli, 1994) In processed meat, the presence of enterococci reflects the extent of initial fecal contamination (Holley et al., 1988).

Enterococci are recognized as opportunistic human pathogens and lately have distinguished themselves as major nosocomial pathogens causing bacteremia, endocarditis, urinary tract, central nervous system, intra-abdominal and pelvic infections (Franz et al., 1999). In addition, enterococci can be also used as an enteric contamination indicator (Foulquie Moreno et al., 2006).
Enterococci are also known for their capability to exchange genetic information by conjugation (Dunny, 2007) and may spread antibiotic resistance genes among non-pathogenic organisms (Cocconcelli et al., 2003; Fisher and Phillips, 2009) Thus, there is a concern about their presence in uncooked fermented meats because of the contribution they may have to the baseline level of antibiotic resistance in other genera and the potential for transfer of antibiotic resistant bacteria from the indigenous animal microflora to the human gastrointestinal tract (Mathur and Singh, 2005), also leading causes of highly antibiotic-resistant and hospital-acquired infection (Aarestrup et al., 2001). Enterococci are recognized as opportunistic human pathogens, and as indicator for fecal contamination. Due to lack of good hygienic practice in the Libyan slaughterhouses and meat retail markets, therefore, the objectives of this study were to evaluate the presence of enterococci in meat, meat products of different animal species and seafood from different Libyan localities and for their antibiotic resistance profiles.

\section{MATERIAL AND METHODS}

\section{Collection and preparation of samples}

A total of 104 samples (Table 1) included: raw meat samples (51), meat products (30) and seafood (23), were randomly collected from different cities in Libya (Tripoli, Regdalin, Janzour and Tobruk). The samples were packed in sterile plastic bags, stored in an insulated icebox and transferred as quickly as possible to Food Hygiene and Control Laboratory Department, Faculty of Veterinary Medicine, University of Tripoli. All samples were subjected to Enterococcus spp. microbiological enumeration and isolation techniques. Decimal dilutions, culturing and enumeration techniques were performed according to the methods described by the American Public Health Association (APHA) (Downes $\boldsymbol{e}$ t al. 2001). Briefly, $25 \mathrm{~g}$ from each sample was aseptically transferred into a sterile stomacher bag (Seward Medicals, UK) and homogenized (Stomacher 400, Seaward Medicals, UK) with $225 \mathrm{~mL}$ of sterile peptone water $0.1 \%$ (w/v) (Park Scientific, UK) at $230 \mathrm{rpm}$ for $2 \mathrm{~min}$. 


\section{Enumeration and isolation of Enterococcus spp.}

Enumeration and isolation of enterococci were performed using enterococci selective differential agar medium (ESD) (Efthymiou et al., 1974). ESD plates were seeded by surface spreading of $0.1 \mathrm{~mL}$ of appropriate tissue homogenate serial dilutions and then incubated at $37{ }^{\circ} \mathrm{C}$ for $24 \mathrm{~h}$. ESD plates were examined for the presence of either magenta, round, 2-3 mm diameter colonies $(E$ faecalis), or white, round, 2-3 mm diameter colonies (E. faecium), or pink, round, 2-3 mm diameter colonies (E. intermediate). Isolates were identified to the species level by using API 20 Strep system (bioMérieux ${ }^{\circledR}$, France).

\section{Identification of enterococci by PCR and partial sequencing of 16S rDNA DNA extraction and amplification of $16 \mathrm{~S}$ rDNA}

DNA extraction of enterococci isolates was performed by GF-1 bacterial DNA extraction kit (Cat. \# GF-BA-100, Vivantis, Malaysia) as described in a previous study (Azwai et al., 2016). The 16S rDNA was amplified using the universal oligonucleotides primers forward: S-D-Bact-0341-b-S-17 5' CCTACGGGNGGCWGCAG-3' and Reverse: S-D-Bact-0785-a-A-21 5'GACTACHVGGGTATCTAATCC-3' (Herlemann et al., 2011).

\section{Electrophoresis, gel extraction and DNA sequencing}

The amplified 16S rDNA PCR fragment (464 bp) was excised from the gel and the DNA was purified using GF-1 Ambi Clean kit (Cat. \# GF-GC-100, Vivantis, Malaysia) as described in previously (Azwai $\boldsymbol{e t}$ al., 2016). The purified 16S rDNA amplicons underwent cycle sequencing with Big Dye ${ }^{\circledR}$ Terminator v1.1 kit (AB Applied Bioscience, TECHNE, TC-512, USA) and were sequenced on four capillary ABI PRISM $® 3130$-Avant Genetic Analyzer at IZSLER Istituto Zooprofilattico Sperimentale Della Lombardia e dell'Emilia Romagna, Brescia, Italy. Sequences were assembled and edited using the SeqMan module within Lasergene package, (DNA Star Inc., Madison, WI, USA). The obtained consensus sequences were subjected to BLAST search both at NCBI (http://www.ncbi.nlm.nih.gov/pubmed) and at 16S bacterial cultures Blast Server for the identification of prokaryotes (http://bioinfo.unice.fr/blast/).

\section{Antibiogram of isolated strains}

\section{Inoculum Preparation}

Upon confirmation by PCR and partial sequencing of $16 \mathrm{~S}$ rDNA gene isolated strains of enterococci were preserved by freezing at $-80{ }^{\circ} \mathrm{C}$ in vials containing Brain Heart Infusion broth (BHI, Difco, Michigan, USA) supplemented with $30 \%(\mathrm{v} / \mathrm{v})$ glycerol. To propagate the culture, frozen vial was thawed at room temperature, and $0.5 \mathrm{~mL}$ of thawed culture was transferred to $5 \mathrm{~mL}$ of $\mathrm{BHI}$ broth and incubated for $24 \mathrm{~h}$ at $37^{\circ} \mathrm{C}$. The inoculum was prepared from the second transfer of that culture $(0.5 \mathrm{~mL})$ to another $5 \mathrm{~mL}$ of BHI broth and incubated for $16-18 \mathrm{~h}$ at $37{ }^{\circ} \mathrm{C}$. After the overnight incubation Muller Hinton agar plates (Oxoid, Hampshire, UK) were surface swabbed, then the selected antibiotic discs were dispensed and lightly pressed onto the inoculated agar surface according to (Coyle, 2005) then incubated at $37^{\circ} \mathrm{C}$ for $24 \mathrm{~h}$.

\section{Antibiotic assay}

The selection of antibiotics was based on their common use in food animal practice and included: (oxytetracyclin $(30 \mu \mathrm{g})$, streptomycin $(10 \mu \mathrm{g})$ and vancomycin $(30 \mu \mathrm{g}))$. The antibiotic discs were purchased from Oxoid with the exception of the enrofloxacin $(5 \mu \mathrm{g})$, amoxicillin $(25 \mu \mathrm{g})$ obtained from Arcomex Arab (Medical Diagnostics CO., Amman, Jordan), while colistin (10 $\mu \mathrm{g})$, doxycycline $(30 \mu \mathrm{g})$, gentamycin $(10 \mu \mathrm{g})$, erythromycin $(10 \mu \mathrm{g})$, were obtained from Mast Diagnostics (Mast group ltd., Merseside, UK). The clear zones around antibiotic discs that has no growth, referred to as the zone of inhibition, were measured and scored as sensitive, intermediate (reduced susceptibility) or resistant according to the Clinical and Laboratory Standards Institute guidelines (CLSI, 2015)

\section{RESULTS AND DISCUSSION}

\section{Isolation and enumeration of Enterococcus spp.}

One hundred and four samples from various regions of Libya comprising raw meat (51), meat products of different species (30) and seafood (23) were tested for the presence of Enterococcus spp. by using ESD medium (Table 1). Enterococcus spp. were isolated from the samples of raw meat: beef 12/17 $(70.5 \%)$, camel $13 / 22(59 \%)$ and chicken meat $11 / 12(91.6 \%)$ respectively, and from the samples of seafood: fish 5/13 (38.4\%) and shrimp 3/6 (50\%) respectively, with counts ranged from $8.7 \times 10$ to $4.2 \times 10^{4} \mathrm{CFU} / \mathrm{g}$ and the most common isolate was $E$. faecalis. No isolate was detected from clam samples. As for meat products, isolation rate of Enterococcus spp. on ESD agar plates from 30 samples of meat products of different animal species was $100 \%$, except for beef burger, that was $87.5 \%(7 / 8)$ with counts ranged from $7 \times 10^{3}$ to $6.8 \times 10^{6}$ $\mathrm{CFU} / \mathrm{g}$. The maximum mean count of enterococci was recorded in chicken burger $3.8 \times 10^{6} \mathrm{CFU} / \mathrm{g}$; while the minimum mean count was in shrimp $1.1 \times 10^{3} \mathrm{CFU} / \mathrm{g}$ (Table 1). The occurrence of Enterococcus spp. was $87.5 \%$ in beef burger with counts ranging from $1.7 \times 10^{5}$ to $1.4 \times 10^{6} \mathrm{CFU} / \mathrm{g}$ and the mean counts was $7.6 \times 10^{5} \mathrm{CFU} / \mathrm{g}$, meanwhile, in beef kebab the isolation rate was $100 \%$ with counts ranging from $2 \times 10^{4}$ to $1.8 \times 10^{5} \mathrm{CFU} / \mathrm{g}$ and the mean count was $9 \times 10^{4} \mathrm{CFU} / \mathrm{g}$ (Table 1). Detection of enterococci in chicken burger was $100 \%$ with counts ranging from $7.7 \times 10^{5}$ to $6.8 \times 10^{6} \mathrm{CFU} / \mathrm{g}$ with a mean counts $3.8 \times 10^{6} \mathrm{CFU} / \mathrm{g}$. While, in ground chicken the rate was $100 \%$ with counts ranging from $9 \times 10^{3}$ to $8 \times 10^{4} \mathrm{CFU} / \mathrm{g}$ and the mean counts was $4.5 \times 10^{4} \mathrm{CFU} / \mathrm{g}$.

Table 1 Comparison between growth on ESD medium and partial sequencing of 16S rDNA technique for identification of Enterococcus spp.

\begin{tabular}{|c|c|c|c|c|c|}
\hline Type of Sample & $\begin{array}{c}\text { No. of } \\
\text { Samples }\end{array}$ & $\begin{array}{c}\text { No. of Suspected } \\
\text { Enterococcus spp. } \\
\text { Growth on ESD (\%) } \\
\end{array}$ & $\begin{array}{c}\text { Average Count }(\mathrm{CFU} / \mathrm{g}) \\
\text { of Enterococcus spp. on } \\
\text { ESD } \\
\end{array}$ & $\begin{array}{c}\text { No. of } \\
\text { Sequenced } \\
\text { Isolates } \\
\end{array}$ & $\begin{array}{c}\text { No. of Positive } \\
\text { Enterococcus spp. by } \\
\text { 16S rDNA Sequencing }\end{array}$ \\
\hline \multicolumn{6}{|l|}{ Raw meat } \\
\hline Beef & 17 & $12(70.5)$ & $2.2 \times 10^{4}$ & 4 & None \\
\hline Camel meat & 22 & $13(59)$ & $1.6 \times 10^{4}$ & 4 & None \\
\hline Chicken meat & 12 & $11(91.6)$ & $4 \times 10^{3}$ & 4 & None \\
\hline Clam & 4 & 0 & - & - & - \\
\hline Fish & 13 & $5(38.4)$ & $4.4 \times 10^{3}$ & 2 & None \\
\hline Shrimp & 6 & $3(50)$ & $1.1 \times 10^{3}$ & 2 & None \\
\hline \multicolumn{6}{|l|}{ Meat products } \\
\hline Chicken burger & 8 & $8(100)$ & $3.8 \times 10^{6}$ & 4 & 3 \\
\hline Chicken kebab & 2 & $2(100)$ & $9 \times 10^{4}$ & 2 & None \\
\hline Chicken sausage & 2 & $2(100)$ & $9 \times 10^{4}$ & 2 & None \\
\hline Beef burger & 8 & $7(87.5)$ & $7.6 \times 10^{5}$ & 4 & 1 \\
\hline Beef kebab & 2 & $2(100)$ & $9 \times 10^{4}$ & 2 & 1 \\
\hline Beef sausage & 2 & $2(100)$ & $8 \times 10^{4}$ & 2 & None \\
\hline Ground beef & 2 & $2(100)$ & $9 \times 10^{3}$ & 2 & None \\
\hline Ground chicken & 4 & $4(100)$ & $4.5 \times 10^{4}$ & 2 & 1 \\
\hline Total & 104 & $73(70.2)$ & & 36 & 6 \\
\hline
\end{tabular}

Identification of enterococci spp. by PCR and sequencing of partial $16 \mathrm{~S}$ rDNA gene

A total of 36 (16 raw meat samples and 20 meat products samples) randomly selected isolates (36 out of 73 isolates were found to be enterococci based on their cultural characteristics on ESD medium) were sent for partial sequencing of
16S rDNA (464 bp) of enterococci strains using the universal oligonucleotides primers (FOR.: S-D-Bact-0341-b-S-17 and REV.: S-D-Bact-0785-a-A-21) (Fig. 1). Only six isolates (16.6\%) (Table 2) were identified as Enterococcus spp These isolates of enterococci were all isolated from meat products (beef burger, beef kebab, ground chicken and chicken burger) (Table 3 ). 


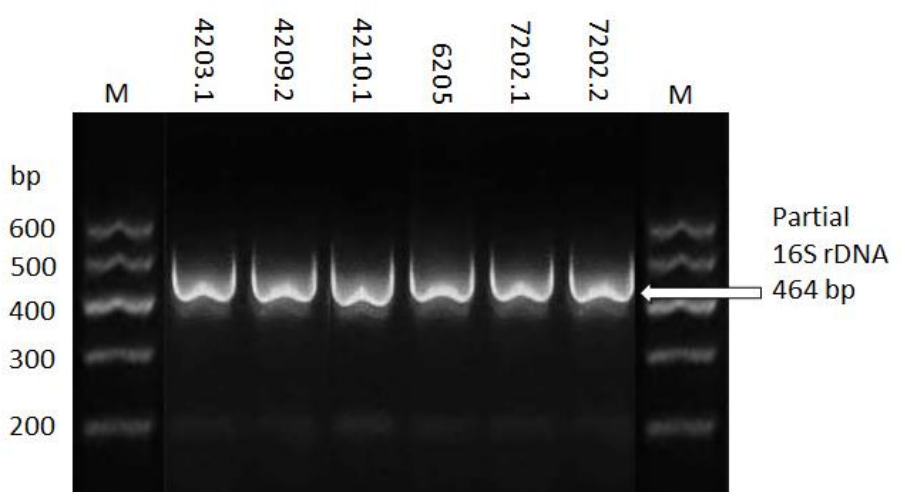

Figure 1 Representative gel of partial amplification of 16S rDNA (464 bp) products of isolated Enterococci strains using the universal oligonucleotides primers. First and last lanes contain DNA marker (M).

Table 2 Convential and molecular identification of suspected Enterococcus spp. in different meat products samples (CFU/g)

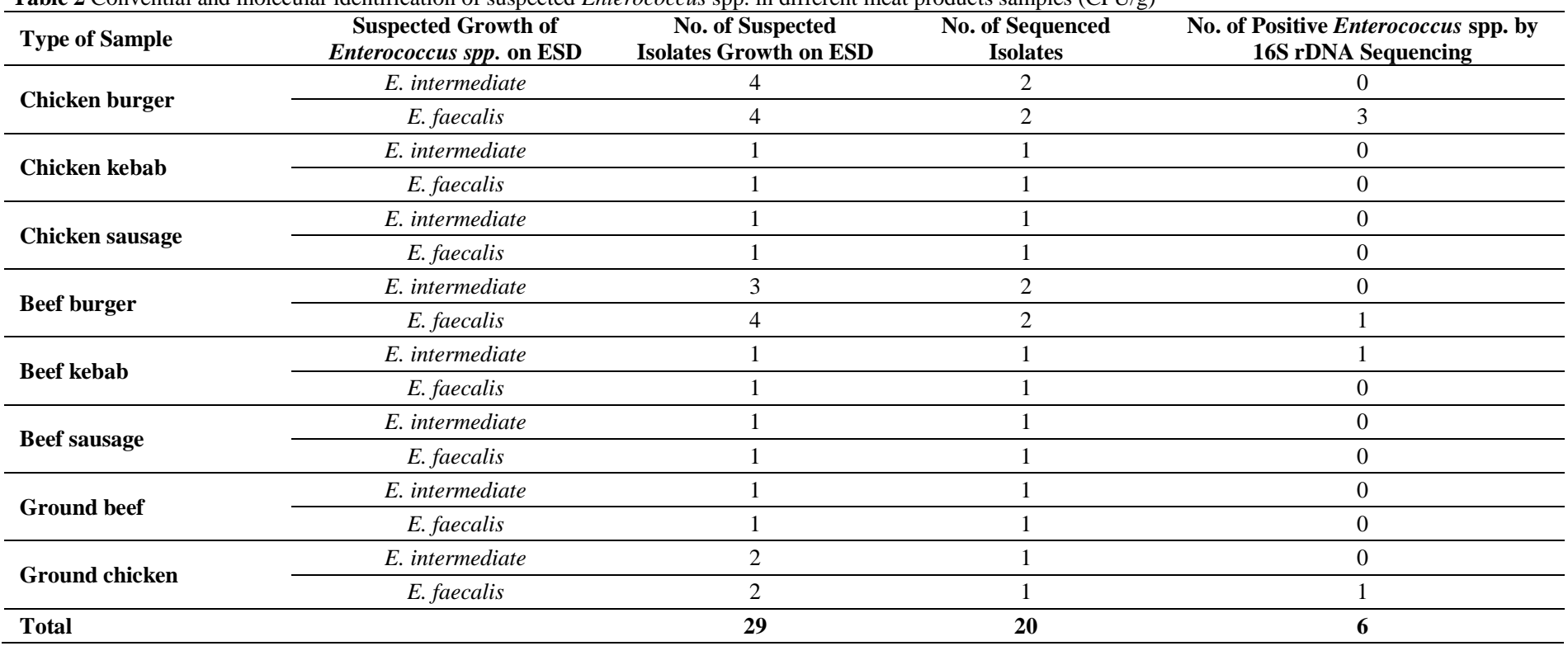

Table 3 Identity of suspected isolate after sequencing by blast NCBI

\begin{tabular}{lcccccc}
\hline Blast NCBI & $\begin{array}{c}\text { Identity } \\
(\boldsymbol{\%})\end{array}$ & Isolate Code & $\begin{array}{c}\text { Suspected Isolate on } \\
\text { ESD }\end{array}$ & Type of Sample & $\begin{array}{c}\text { Storage } \\
\text { Condition }\end{array}$ & Source \\
\hline Enterococcus durans & 100 & 4203.1 & Enterococci & Beef burger & Frozen & Suqaljuma, Tripoli \\
\hline Enterococcus faecium & 100 & 4209.2 & Enterococci & Chicken burger & Frozen & Salaheldin Tripoli \\
\hline Enterococcus durans & 100 & 4210.1 & Enterococci & Beef kebab & Chilled & Salaheldin Tripoli \\
\hline Enterococcus faecalis & 100 & 6205 & Enterococci & Ground chicken & Chilled & Suqaljuma, Tripoli \\
\hline Enterococcus faecium & 100 & 7202.1 & Enterococci & Chicken burger & Frozen & Abusetta, Tripoli \\
\hline Enterococcus durans & 100 & 7202.2 & Enterococci & Chicken burger & Frozen & Abusetta, Tripoli \\
\hline
\end{tabular}

\section{Antibiotics Resistant Phenotype}

The results (Table 4) showed testing of the six confirmed enterococci isolates from meat products against nine antimicrobial agents (amoxicillin, colistin, doxycycline, enrofloxacin, erythromycin, gentamycin, oxytetracyclin, streptomycin and vancomycin). Antibiotic resistance profile showed that, $E$. durans found in beef burger and E. faecium found in chicken burger were resistant to five out of nine antibiotics $(55.5 \%)$. Meanwhile, E. durans from beef kebab and E. faecalis from chicken burger both were resistant to seven out of nine antibiotics $(77.7 \%)$. On the other hand E. faecalis from ground chicken showed resistance to eight out of nine (88.8\%), lastly E. durans from chicken burger was resistant to six out of nine $(66.6 \%)$. In conclusion, enterococci isolates exhibited resistance to at least five out of nine (55.5\%) of the tested antibiotics. All six enterococci isolates $(100 \%)$ were resistant to colistin. While five out of six tested isolates (83.3\%) were resistant to amoxicillin, enrofloxacin, erythromycin and streptomycin. Resistance to oxytetracyclin and doxycycline was recorded among $66.6 \%$ of the isolates. However, only two isolates $(33.3 \%)$ were resistant to gentamycin and vancomycin (Table 4). 
Table 4 Sensitivity of six strains of enterococci to nine antibiotics Antibiotic Discs (mm)

\begin{tabular}{|c|c|c|c|c|c|c|c|c|c|c|c|c|}
\hline Enterococci Strains & 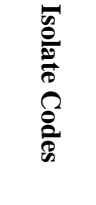 & 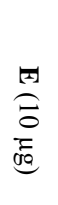 & 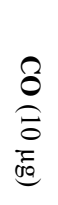 & 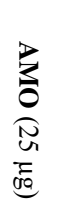 & 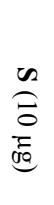 & 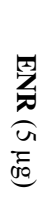 & 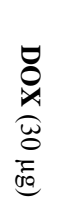 & 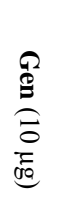 & 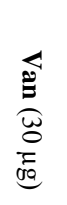 & 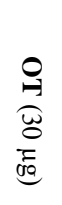 & $\mathbf{R} \%$ & $\mathbf{S \%}$ \\
\hline Enterococcus durans & 4203.1 & $\begin{array}{l}20 \\
(\mathrm{~S}) \\
\end{array}$ & (R) & $(\mathrm{R})$ & $(\mathrm{R})$ & $\begin{array}{c}9 \\
(\mathrm{R}) \\
\end{array}$ & $\begin{array}{l}25 \\
(\mathrm{~S}) \\
\end{array}$ & $\begin{array}{c}12 \\
\text { (R) }\end{array}$ & $\begin{array}{l}20 \\
(\mathrm{~S}) \\
\end{array}$ & $\begin{array}{c}21 \\
(\mathrm{~S})\end{array}$ & 55.5 & 44.5 \\
\hline Enterococcus faecium & 4209.2 & $\begin{array}{c}12 \\
(\mathrm{R})\end{array}$ & (R) & $(\mathrm{R})$ & (R) & $\begin{array}{c}12 \\
\text { (R) }\end{array}$ & $\begin{array}{l}23 \\
(\mathrm{~S})\end{array}$ & $\begin{array}{l}16 \\
(\mathrm{~S})\end{array}$ & $\begin{array}{l}19 \\
\text { (S) }\end{array}$ & $\begin{array}{l}21 \\
(\mathrm{~S})\end{array}$ & 55.5 & 44.5 \\
\hline Enterococcus durans & 4210.1 & $\begin{array}{c}11 \\
(\mathrm{R}) \\
\end{array}$ & (R) & $(\mathrm{R})$ & (R) & $\begin{array}{c}13 \\
(\mathrm{R}) \\
\end{array}$ & $\begin{array}{c}10 \\
(\mathrm{R})\end{array}$ & $\begin{array}{l}15 \\
(\mathrm{~S}) \\
\end{array}$ & $\begin{array}{c}17 \\
(\mathrm{~S}) \\
\end{array}$ & (R) & 77.7 & 22.3 \\
\hline Enterococcus faecalis & 6205 & (R) & (R) & $\begin{array}{l}16 \\
(\mathrm{~S}) \\
\end{array}$ & (R) & $\begin{array}{c}16 \\
\text { (R) } \\
\end{array}$ & $(\mathrm{R})$ & $(\mathrm{R})$ & (R) & $(\mathrm{R})$ & 88.8 & 11.2 \\
\hline Enterococcus faecium & 7202.1 & $(\mathrm{R})$ & (R) & $(\mathrm{R})$ & (R) & $\begin{array}{l}13 \\
(\mathrm{R}) \\
\end{array}$ & $\begin{array}{c}10 \\
(\mathrm{R})\end{array}$ & $\begin{array}{l}15 \\
(\mathrm{~S}) \\
\end{array}$ & $\begin{array}{l}17 \\
(\mathrm{~S}) \\
\end{array}$ & $(\mathrm{R})$ & 77.7 & 22.3 \\
\hline Enterococcus durans & 7202.2 & $(\mathrm{R})$ & (R) & (R) & $\begin{array}{l}20 \\
\text { (S) } \\
\end{array}$ & $\begin{array}{l}20 \\
(\mathrm{~S}) \\
\end{array}$ & $(\mathrm{R})$ & $\begin{array}{l}23 \\
(\mathrm{~S})\end{array}$ & $(\mathrm{R})$ & $(\mathrm{R})$ & 66.6 & 33.4 \\
\hline R\% & & 83 & 100 & 83 & 83 & 83 & 66.6 & 33.3 & 33.3 & 66.6 & & \\
\hline $\mathbf{S \%}$ & & 17 & $\mathbf{0}$ & 17 & 17 & 17 & 33.4 & 66.6 & 66.6 & 33.4 & & \\
\hline
\end{tabular}

(S): Sensitive, (R): Resistant, E: erythromycin, CO: colistin, AMO: amoxicillin, S: streptomycin, ENR: enrofloxacin, DOX: doxycycline, Gen: gentamycin, Van: vancomycin, and OT: oxytetracyclin.

\section{DISCUSSION}

Enterococcus spp. are widely distributed in nature and are associated with the spoilage of meat and meat products (Hugas et al., 2003). Current study was conducted to isolate Enterococcus spp. from 104 samples of different meat, meat products of different animal species and seafood, collected from various geographical places in Libya. This study reported the presence of Enterococcus spp. in most meat and all local un-heat treated meat products samples except one sample of beef burger by conventional cultural method. Generally, the incidence of Enterococcus spp. all over the collected samples of raw meat was $70.5 \%$ $(36 / 51)$ and seafood was $34 \%(8 / 23)$. However, the incidence rate of enterococci in meat products was $96.6 \%$ (29/30); this high incidence in meat products could be attributed to low hygienic practice and cross contamination during preparation of such products. The results showed that the contamination with Enterococcus spp. in meat of different animal species and meat products was higher than that in seafood. The higher values could be as a result of contamination from the processing area, equipment used, also the means of transportation which was used in bringing the produce to the market centers and the hygienic practice employed by meat sellers and butchers. The meat during its preparation remains in the ground for a long time which creates a good environment for microbia pathogens to proliferate on it. On the other hand, seafood were sold at the seafood market freshly with better hygienic conditions that reduce the possibility from being contaminated (Franz et al., 2003).

The occurrence of Enterococcus spp. in meat of different animal species and seafood (73) was in beef, camel, chicken, fish and shrimp 70.5\%, 59\%, 91.6\%, 38.4 and $50 \%$ respectively, with counts ranging from $1.5 \times 10^{4}$ to $6.8 \times 10^{6} \mathrm{CFU} / \mathrm{g}$ (Table 1). The average counts of Enterococcus spp. in camel meat was $1.6 \times 10^{4}$ $\pm 1.2 \times 10^{4} \mathrm{CFU} / \mathrm{g}$. Hugas et al. (2003) reported that the numbers of viable count of enterococci in contaminated beef, poultry and pork are usually in the range of $10^{2}$ - $10^{4} \mathrm{CFU} / \mathrm{g}$. Meanwhile, our study did not detect enterococci among four examined samples of clam (bivalve shellfish). In contrary to Montiel et al. (2013) who found enterococci in all samples of clam examined with their densities generally higher in clams than sediment and water. Our result could be due to Enterococcus spp. were removed from hard shell clams by depuration occurred at the fish market where the samples were collected (Love et al., 2010). On the other hand, 30 samples of meat products revealed an incidence of $100 \%$ Enterococcus spp., except in beef burger was $87.5 \%$ (Table 1). The mean counts of enterococci were $2.2 \times 10^{4} \mathrm{CFU} / \mathrm{g}$ in beef, $3.8 \times 10^{6} \mathrm{CFU} / \mathrm{g}$ in chicken burger, $9 \times 10^{4} \mathrm{CFU} / \mathrm{g}$ in chicken kebab and beef Kebab, chicken sausage and ground beef, $8 \times 10^{4} \mathrm{CFU} / \mathrm{g}$ in beef sausage, and $4.5 \times 10^{4} \mathrm{CFU} / \mathrm{g}$ in ground chicken. Our study revealed that, the highest enterococci count was in chicken burger $3.8 \times 10^{6}$ $\mathrm{CFU} / \mathrm{g}$, however, the lowest count $1.1 \times 10^{3} \mathrm{CFU} / \mathrm{g}$ was recorded in shrimp. The most common enterococci recorded in our investigation in meat products were $E$. durans, E. faecalis and E. faecium, while, (Jahan et al., 2013; Sadeghifard $\boldsymbol{e}$ al., 2015) reported E. faecalis as a predominant isolate in all meat samples. In agreement with our findings, Naas et al. (2009a,b) recorded high enumeration of enterococci in all tested samples that included beef burger and beef sausage at rate of $2 \times 10^{7}$ and $9 \times 10^{6} \mathrm{CFU} / \mathrm{g}$ respectively. As for molecular confirmation only six out of 36 randomly selected enterococci isolates were identified and confirmed by partial sequencing of $16 \mathrm{~S}$ rDNA, (8.2\%) were confirmed as Enterococcus spp. in particular E. durans, E. faecalis and E. faecium (Table 3).
Enterococci raise major concern during the last decades, as they are becoming one of the most important nosocomial infections causing serious illnesses in human. The presence of Enterococcus spp. in foods may act as reservoir of antibiotic resistance genes (Valenzuela $\boldsymbol{e t}$ al., 2009). The susceptibility of enterococci isolates to different antibiotics was tested (Table 4) and the highest incidence of resistance was recorded to colistin (100\%), colistin is a last-resort antibiotic in both animals and humans, this antibiotic is used against particularly dangerous types of multi resistant bacteria that can withstand many other antibiotics. The existence of such isolates in the food chain of humans is of a great concern not only to public health but also because of the ease of resistance gene transfer to other bacteria. Lower resistance rates $(83 \%)$ were recorded against erythromycin, amoxicillin, streptomycin and enrofloxacin while it was $(66.6 \%)$ to oxytetracyclin and doxycyclin. Only $33.3 \%$ of the isolates were resistant to vancomycin and gentamicin, similar results were recorded by Jahan et al. (2013). Vancomycin resistant enterococci (VRE) are nosocomial pathogens that have been detected in environmental habitats including soil, water and wildlife faces. The spread of opportunistic pathogens harboring VR genes beyond hospitals into community is a potential threat to public health as vancomycin is used as last-resort against many infections. Most of the isolated enterococci strains were resistant to more than five antibiotics out of nine $(55.5 \%)$. In the contrary to Fracalanzza et al. (2007) who found overall percentages of antimicrobial resistant of isolates were: $31.2 \%$ to tetracycline, $23.8 \%$ to erythromycin, $11.3 \%$ to streptomycin, $4.3 \%$ to chloramphenicol, $3.9 \%$ to gentamicin, $1.4 \%$ to enrofloxacin and $0.4 \%$ to ampicillin. In another work, Klibi et al. (2013) studied enterococci strains isolated from meat samples that showed $14 \%$ resistance to streptomycin and $100 \%$ to streptomycin and tetracycline.

\section{CONCLUSION}

In conclusion, our findings demonstrated the presence of Enterococcus spp. in meat, meat products of different animal species and seafood. Vancomycin resistant enterococci were also isolated from local meat products sold in different cities in Libya. Moreover, conventional cultural methods on ESD medium were less significant than using the molecular techniques as partial sequencing of $16 \mathrm{~S}$ rDNA techniques for identification of enterococci. Only six enterococci isolates cultured on ESD medium were confirmed to be Enterococcus spp. by PCR and partial sequencing of $16 \mathrm{~S}$ rDNA. The occurrence of resistant strains of enterococci in food of animal origin should be considered as important threat to public health.

Acknowledgments: This study was part of a project titled "Genetic authentication of bacterial isolates from meat and milk products in Libya and establishing the Food-borne Libyan-type Bacterial Collection (FLBC)" that was supported by a grant provided by the Libyan Authority for Research, Science and Technology (LARST). Authors are grateful to Veronica Papini, a technician in Istituto Zooprofilattico Sperimentaledella Lombardia e dell'Emilia Romagna, Brescia, Italy, who performed the sequencing of the partial $16 \mathrm{~S}$ rDNA.

\section{REFERENCES}

Aarestrup, F.M., Seyfarth, A.M., Emborg, H.D., Pedersen, K., Hendriksen, R.S. \& Bager, F. (2001). Effect of abolishment of the use of antimicrobial agents for 
growth promotion on occurrence of antimicrobial resistance in fecal enterococci from food animals in Denmark. Antimicrobial agents and chemotherapy, 45, 2054-2059. http://dx.doi.org/10.1128/aac.45.7.2054-2059.2001

Azwai, S.M., Alfallani, E.A., Abolghait, S.K., Garbaj, A.M., Naas, H.T. Moawad, A.A., Gammoudi, F.T., Rayes, H.M., Barbieri, I. \& Eldaghayes, I.M (2016). Isolation and molecular identification of Vibrio spp. by sequencing of $16 \mathrm{~S}$ rDNA from seafood, meat and meat products in Libya. Open Veterinary Journal, 6(1), 36-43. http://dx.doi.org/10.4314/ovj.v6i1.6

Choi, J.M., \& Woo, G.J. (2013). Molecular characterization of high-leve gentamicin-resistant Enterococcus faecalis from chicken meat in Korea. International Journal of Food Microbiology, 165, 1-6. http://dx.doi.org/10.1016/j.ijfoodmicro.2013.02.016

Cocconcelli, P.S., Cattivelli, D., \& Gazzola, S. (2003). Gene transfer of vancomycin and tetracycline resistances among Enterococcus faecalis during cheese and sausage fermentations. International Journal of Food Microbiology, 88, 315-323. http://dx.doi.org/10.1016/s0168-1605(03)00194-6

Coyle M. B. (2005). Manual of Antimicrobial Susceptibility Testing; American Society for Microbiology Press, Washington D.C. pp 25, 39.

Downes, F.P., Ito, K., \& Association, A.P.H. (2001). Compendium of Methods for the Microbiological Examination of Foods (American Public Health Association). http://dx.doi.org/10.2105/9780875531755

Dunny, G.M. (2007). The peptide pheromone-inducible conjugation system of Enterococcus faecalis plasmid pCF10: cell-cell signalling, gene transfer, complexity and evolution. Philosophical transactions of the Royal Society of London Series B, Biological Sciences, 362, 1185-1193. http://dx.doi.org/10.1098/rstb.2007.2043

Efthymiou, C.J., Baccash, P., Labombardi, V.J., \& Epstein, D.S. (1974) Improved isolation and differentiation of enterococci in cheese. Applied Microbiology, 28, 417-422.

Fisher, K., \& Phillips, C. (2009). The ecology, epidemiology and virulence of $\begin{array}{llll}\text { Enterococcus. } & \text { Microbiology, } & 155, & 1749-1757\end{array}$ http://dx.doi.org/10.1099/mic.0.026385-0

Foulquie Moreno, M.R., Sarantinopoulos, P., Tsakalidou, E., \& De Vuyst, L. (2006). The role and application of enterococci in food and health. International $\begin{array}{lllll}\text { Journal of Food } & \text { Microbiology, } & 106, & 1-24\end{array}$ http://dx.doi.org/10.1016/j.ijfoodmicro.2005.06.026

Fracalanzza, S.A., Scheidegger, E.M., Santos, P.F., Leite, P.C., \& Teixeira, L.M. (2007). Antimicrobial resistance profiles of enterococci isolated from poultry meat and pasteurized milk in Rio de Janeiro, Brazil. Memorias do Instituto Oswaldo Cruz, 102, 853-859. http://dx.doi.org/10.1590/s007402762007005000120

Franz, C.M., Holzapfel, W.H., \& Stiles, M.E. (1999). Enterococci at the crossroads of food safety?. International Journal of Food Microbiology, 47, 1-24. http://dx.doi.org/10.1016/s0168-1605(99)00007-0

Giraffa, G. (2003). Functionality of enterococci in dairy products. International Journal of Food Microbiology, 88, 215-222. http://dx.doi.org/10.1016/s01681605(03)00183-1

Hartman, P.A., Deibel, R.H., \& Sieverding, L.M. (2001). Enterococci. In Compendium of Methods for the Microbiological Examination of Foods, F.P Downes, and K. Ito, eds. (Washington, DC: American Public Health Association), pp. 83-87. http://dx.doi.org/10.2105/9780875531755ch09

Herlemann, D.P., Labrenz, M., Jurgens, K., Bertilsson, S., Waniek, J.J., \& Andersson, A.F. (2011). Transitions in bacterial communities along the $2000 \mathrm{~km}$ salinity gradient of the Baltic Sea. The ISME Journal, 5, 1571-1579. http://dx.doi.org/10.1038/ismej.2011.41

Holley, R.A., Lammerding, A.M., \& Tittiger, F. (1988). Occurrence and significance of streptococci in fermented Italian type dry sausage. International Journal of Food Microbiology, 7, 63-72. http://dx.doi.org/10.1016/01681605(88)90073-6

Hugas, M., Garriga, M., \& Aymerich, M.T. (2003). Functionality of enterococci in meat products. International Journal of Food Microbiology, 88, 223-233. http://dx.doi.org/10.1016/s0168-1605(03)00184-3

Jahan, M., Krause, D.O., \& Holley, R.A. (2013). Antimicrobial resistance of Enterococcus species from meat and fermented meat products isolated by a PCRbased rapid screening method. International Journal of Food Microbiology, 163 89-95. http://dx.doi.org/10.1016/j.ijfoodmicro.2013.02.017

CLSI. (2015). Performance Standards for Antimicrobial Susceptibility Testing; Twenty-Fifth Informational Supplement. CLSI document M100-S25. Wayne, PA: Clinical and Laboratory Standards Institute. Vol. 35 No. 3.

Knudtson, L.M., \& Hartman, P.A. (1993). Comparison of fluorescent gentamicin-thallous-carbonate and KF streptococcal agars to enumerate enterococci and fecal streptococci in meats. Applied and Environmental Microbiology, 59, 936-938.

Love, D.C., Lovelace, G.L., \& Sobsey, M.D. (2010). Removal of Escherichia coli, Enterococcus fecalis, coliphage MS2, poliovirus, and hepatitis A virus from oysters (Crassostrea virginica) and hard shell clams (Mercinaria mercinaria) by depuration. International Journal of Food Microbiology, 143, 211-217. http://dx.doi.org/10.1016/j.ijfoodmicro.2010.08.028
Mathur, S., \& Singh, R. (2005). Antibiotic resistance in food lactic acid bacteria-a review. International Journal of Food Microbiology, 105, 281-295. http://dx.doi.org/10.1016/j.ijfoodmicro.2005.03.008

Montiel, M., Silva, R., Núñez, J., Morales, F., Severeyn, H., \& García, Y. (2013). Enteroccoccus in Water, Sediment and Clams in a Tropical Environment, Maracaibo Lake, Venezuela. Journal of Marine Science: Research \& Development, 3, 1000133. http://dx.doi.org/10.4172/2155-9910.1000133

Murray, B.E. (1990). The life and times of the Enterococcus. Clinical Microbiology Reviews, 3, 46-65. http://dx.doi.org/10.1128/cmr.3.1.46

Naas, H. T., Garbaj, A. M., Elarbed, Z. M., Eshamah, H. L., \& Abolghit, S.K (2009a). Microbial status of beef brurger sold in Tripoli. Journal of Egyptian Academic society for Environmental Development, 10(2), 139-144.

Naas, H. T., Garbaj, A. M., Elarbed, Z. M., Eshamah, H. L., \& Abolghit, S.K. (2009b). Microbial status of fresh beef sausage sold in Tripoli. Suez Canal veterinary Medicine Journal, IVX(2), 111-118.

Schleifer, K.H. \& Kilpper-Bälz, R. (1987). Molecular and chemot-axonomic approaches to the classification of streptococci, enterococci and Lactococci: A Review. Systemic and Applied Micrbiology, 10, 1-19. http://dx.doi.org/10.1016/s0723-2020(87)80002-4

Sharifi, Y., Hasani, A., Ghotaslou, R., Naghili, B., Aghazadeh, M., Milani, M., \& Bazmany, A. (2013). Virulence and antimicrobial resistance in enterococci isolated from urinary tract infections. Advanced Pharmaceutical Bulletin, 3, 197201

Sparo, M.D., Confalonieri, A., Urbizu, L., Ceci, M., \& Bruni, S.F. (2013). Biopreservation of ground beef meat by Enterococcus faecalis CECT7121. Brazilian Journal of Microbiology, 44, 43-49. http://dx.doi.org/10.1590/s1517$\underline{83822013005000003}$

Turtura, G.C., \& Lorenzelli, P. (1994). Gram-positive cocci isolated from slaughtered poultry. Microbiological Research, 149, 203-213. http://dx.doi.org/10.1016/s0944-5013(11)80120-5

Valenzuela, A.S., Ben-Omar, N., Abriouel, H., López, R.L., Veljovic, K. Cañamero, M.M., Topisirovic, M.K.L., \& Gálvez, A. (2009). Virulence factors, antibiotic resistance, and bacteriocins in enterococci from artisan foods of animal

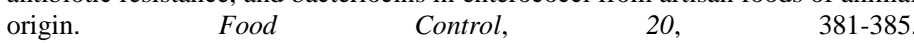
http://dx.doi.org/10.1016/j.foodcont.2008.06.004 